\title{
REPRESENTAÇÕES DA MULHER EM CARTAS BÍBLICAS ANALISADAS SOB A PERSPECTIVA SISTÊMICO-FUNCIONAL*
}

\author{
REPRESENTACIÓN DE LA MUJER EN CARTAS BIBLICAS ANALISADAS POR LA PERSPECTIVA \\ SISTÉMICA FUNCIONAL \\ REPRESENTATIONS OF WOMAN IN BIBLICAL LETTERS ANALIZED UNDER THE SYSTEMIC \\ FUNCTIONAL PERSPECTIVE
}

\author{
Angela Maria Rossi** \\ Gésselda Somavilla Farencena*** \\ Universidade Federal de Santa Maria - UFSM, Santa Maria, BR
}

\begin{abstract}
RESUMO: Este artigo tem como objetivo analisar como a linguagem é usada para representar a mulher em duas cartas bíblicas do Novo Testamento sob o enfoque da Gramática Sistêmico-Funcional, de Halliday e Matthiessen (2004). Para isso, utilizamo-nos de categorias que realizam as três metafunções da linguagem. Na metafunção ideacional, ocupamo-nos do sistema de transitividade; da metafunção interpessoal, focalizamos o sistema de MODO e a polaridade; na metafunção textual, detemo-nos na estrutura temática. A análise conjunta dessas categorias evidenciou que a escolha pelo Tema Ideacional conjugada à função de fala proposta direcionada à mulher e às funções léxico-gramaticais de Ator, Experienciador e Portador desempenhadas por esse participante representam a mulher principalmente como submissa ao homem, ao marido e à sociedade.

PALAVRAS-CHAVE: gramática sistêmico-funcional; representação; mulher; cartas bíblicas.
\end{abstract}

RESUMEN: Este artículo pretende analizar como se utiliza el lenguaje para representar a las mujeres en dos cartas bíblicas del Nuevo Testamento bajo el enfoque sistémico de la Gramática Funcional, de Halliday y Matthiessen (2004). Para conseguirlo, utilizamos categorías que efctivam las tres metafunções del lenguaje. En la metafunción ideacional, tratamos con el sistema de transitividad; en la metafunción interpersonal, nos centramos en el sistema de MODO y en la polaridad; en la metafunción textual, reflexionamos sobre la estructura temática. El análisis conjunto de estas categorías mostró que la elección del tema ideacional combinado com la función de habla propuesta dirigida a las mujeres y a las funciones lexicogramaticales Actor, Experimentador y Portador realizadas por el participante representam a la mujer principalmente como sumisa al hombre, al marido y a la sociedad. PALABRAS CLAVE: gramática sistémica funcional; la representación; mujer; cartas bíblicas.

ABSTRACT: This article aims to analyze how language is used to represent women in two biblical letters of the New Testament from the standpoint of the Systemic Functional Grammar, by Halliday and Matthiessen (2004). Therefore, we used categories that realize the three language metafunctions. From the ideational experiential metafunction we used the transitivity system; from the interpersonal metafunction we focused on the MODE system and polarity; and from the textual metafunction we concentrated on the thematic structure. The whole analysis of these categories showed that the choice of the Ideational Theme conjugated to the speech function toward women and the lexicogrammar functions of Actor, Senser and Carrier performed by this participant represent women primarily as submissive to men, husband, society and the laws and rules that govern it.

KEYWORDS: systemic functional grammar; representation; women; biblical letters.

\section{INTRODUÇÃO}

A abordagem funcionalista de linguagem de base hallidayana vem conquistando espaço no cenário da pesquisa no Brasil e despertando o interesse de pesquisadores a estudarem-na e a desenvolverem estudos utilizando suas categorias de análise. Trabalhos como de Caldeira (2006), Cabral (2002; 2007), Fuzer (2008), Assumpção (2008), Dalla Corte (2009), Rodrigues (2010), Farencena (2011), Sayão (2011) e Silva

\footnotetext{
* Trabalho apresentado à Disciplina de "Gramática Sistêmico-Funcional" ministrado pela Professora Dra. Cristiane Fuzer, durante o $1^{\circ}$ semestre letivo de 2013 da Universidade Federal de Santa Maria. Agradecemos à professora pela contribuições ao texto.

** Angela Maria Rossi é graduada em Letras/Português pelo Centro Universitário Franciscano e mestranda em Estudos Linguísticos pela Universidade Federal de Santa Maria, área de concentração Estudos Linguísticos. Tem experiência em educação a distância, atuando como tutora. Atua como professora de Língua Portuguesa na Escola Técnica Albert Einstein.

*** Gessélda Somavilla Farencena é doutoranda em Letras pela Universidade Federal de Santa Maria, área de concentração Estudos Linguísticos. Em 2011, concluiu Mestrado também em Estudos Linguísticos na mesma universidade. Atua como Professora Substituta na Universidade Federal de Santa Maria (UFSM) e desenvolve estudos e pesquisas em Linguística Aplicada com foco na Linguística Sistêmico-Funcional, abordando como temas a gramática sistêmico-funcional, a teoria da avaliatividade, representações sociais os gêneros textuais. Email: gesseldaf@yahoo.com.br.
} 
(2012) são alguns exemplos. Em comum, todos coadunam-se a Halliday (1989) quanto à concepção de linguagem como um sistema intrínseco às experiências humanas, que combina elementos semióticos e sociais, e por meio da qual, organizada como um sistema instanciado em textos, torna possível a interação e a comunicação verbal entre grupos sociais.

Ao interagir e comunicar-se, esclarecem Halliday e Matthiessen (2004), ao fazer uso da linguagem, escolhas são feitas dentre um grande número de opções que o sistema linguístico disponibiliza. Essas escolhas, de certa forma, conduzem as interações ao construírem diferentes representações de experiências e do mundo. Nesse sentido, entendemos que os textos bíblicos, por meio das representações que manifestam, perpetuamse nas relações sociais como pretensos orientadores ou até regradores de comportamentos, dessa forma, interagindo com seu leitor de modo a agir sobre ele.

Em decorrência disso, chama-nos a atenção o fato de os textos bíblicos, escritos por diversos autores que viveram em épocas diferentes, permanecerem evidentes na sociedade por tanto tempo. De acordo com Hoerlle (2009), a Bíblia é o livro mais traduzido, distribuído e lido de todos os tempos. Além disso, conforme dados extraídos da Sociedade Bíblica do Brasil (ABNB n. 215, p. 28), "está disponível pelo menos em parte em 2.426 línguas o que equivale a 95\% da população mundial”.

Segundo a própria Bíblia, tradução da Conferência Nacional dos Bispos do Brasil (CNBB, 2010, p. 1), "importa compreender a Bíblia no mesmo espírito em que foi escrita [...] e sua "leitura não é literalista, procurando entender tudo “ao pé da letra”. Tendo isso em vista, com este trabalho, buscamos fazer uma leitura analítica sob um olhar sistemicista de linguagem de duas cartas bíblicas procurando entender e evidenciar como a mulher é representada nesses textos e de que forma. Partindo do pressuposto de que a linguagem representa as experiências dos indivíduos e as relações estabelecidas entre eles (HALLIDAY; MATTHIESSEN, 2004), a análise da Primeira Carta de Pedro, direcionada para as comunidades do norte da Ásia Menor (Turquia), que era habitada por colonos situados pelo império Romano, gregos e bárbaros, e da Primeira Carta aos Coríntios, direcionada à comunidade de Coríntios, pode revelar informações e representações sobre a mulher e sua condição social na época.

Para empreendermos essa análise, buscamos o embasamento teórico nas três metafunções da Gramática Sistêmico-Funcional (doravante GSF), pois nos oferecem categorias analíticas que nos permitem explorar as escolhas linguísticas e os significados que elas constroem visando a evidenciar representações para a mulher. Consoante a isso, entendendo que a produção de um texto é decorrente do objetivo que se pretende atingir em determinado momento sociocultural, descrevemos o contexto de situação tendo como base Halliday (1989). Para explorarmos os significados ideacionais, fazemos a descrição das funções léxicogramaticais desempenhadas pelo item lexical "mulher" nos dois textos, tomando por base o sistema de transitividade (HALLIDAY; MATTHIESSEN, 2004). Para tratarmos dos significados interpessoais que permitem reconhecer os papéis que os participantes da interação representam e como se relacionam, analisamos as realizações do sistema de MODO e da polaridade (HALLIDAY; MATTHIESSEN, 2004). Finalmente, para analisarmos os significados textuais, detemo-nos na estrutura temática (HALLIDAY; MATTHIESSEN, 2004) para identificar quais os componentes da mensagem são tematizados. Realizadas essas etapas, os dados obtidos são interpretados em conjunto para identificar as representações construídas pela linguagem para a mulher nas duas cartas bíblicas do Novo Testamento.

Sob essa perspectiva de análise, uma vasta quantidade de trabalhos que abordam a temática feminina já foram publicados, porém, dentre os lidos até o momento, não encontramos nenhum que enfocasse as três metafunções conjuntamente, mas apenas duas delas: a experiencial e a interpessoal. Dentre esses trabalhos, citamos Oliveira (2007), que trata da representação feminina em músicas funk popularizadas a partir de 2004. Uma de suas conclusões indica que os processos verbais são usados para criar um espaço social de inferiorização feminina, haja vista que a voz masculina é sempre representada como superior a feminina. Assumpção (2008), em sua análise, identifica as representações que a mídia impressa constrói para a mulher profissional em revistas brasileiras e norteamericanas. Em uma de suas conclusões, a autora esclarece que as mulheres são representadas por meio de processos materiais que constrói uma representação de uma mulher que atua em termos de avanços profissionais. Morais (2008) busca compreender como as escolhas linguísticas representam as mulheres na política. Uma de suas conclusões evidencia que as mulheres são representadas por meio de suas características femininas e não por sua competência profissional. Rodrigues (2010) pretendendo compreender como a mulher é representada em letras de música de forró eletrônico, evidencia que a mulher é representada como objeto de prazer sexual masculino. 
Assim sendo, o artigo proposto, além de contribuir para ampliar os estudos de LSF, contribuirá para elucidar estruturas linguísticas para construir representações no contexto dos escritos bíblicos, tendo em vista que, até o momento, ainda não encontramos trabalhos desenvolvidos que se dedicassem à análise da temática feminina em textos bíblicos sob a perspectiva da GSF hallidayana e, de modo especial, abordando as três metafunções da linguagem.

Esses aportes teóricos são apresentados na próxima seção, a qual iniciamos com considerações sobre a Linguística Sistêmico-Funcional. Na sequência, com base em Halliday (1989) e Halliday e Matthiessen (2004), expomos, em três subseções, as categorias de análise efetivamente observadas neste estudo, advindas das três metafunções hallidayanas. Concluída a explanação teórica, apresentamos nossas escolhas metodológicas. Em seguida, trazemos a análise e a discussão dos resultados obtidos. Por fim, expomos algumas considerações finais que julgamos relevantes.

\section{LINGUÍSTICA SISTÊMICO- FUNCIONAL}

Considerando a linguagem como um processo interativo e social, a Linguística Sistêmico-Funcional (doravante LSF) compreende a língua em uso. Dessa forma, a linguagem é compreendida a partir de seu caráter social e de sua capacidade de se adequar a diferentes contextos e representá-los (HALLIDAY; MATTHIESSEN, 2004). Dito de outro modo, a linguagem é entendida como um sistema sociossemiótico por meio do qual as pessoas representam suas experiências, interagem e agem sobre os outros e sobre o mundo (HALLIDAY; MATTHIESSEN, 2004). Esse sistema sociossemiótico e, por conseguinte, a linguagem, são materializados em texto, definido por Halliday e Matthiessen (2004, p. 3) ${ }^{1}$ ) como "qualquer instância da linguagem, em qualquer meio, que faz sentido a alguém que conhece a linguagem”. Assim, a linguagem é vista não como um conjunto de regras, mas como um sistema com recursos para descrever, interpretar e construir significados. Os significados resultantes de escolhas realizadas pelos usuários estão vinculados, em um plano mais amplo, ao contexto de cultura, e, em um plano mais específico, ao contexto de situação, como mostra a Figura 01.

Figura 1 - Texto em contextos

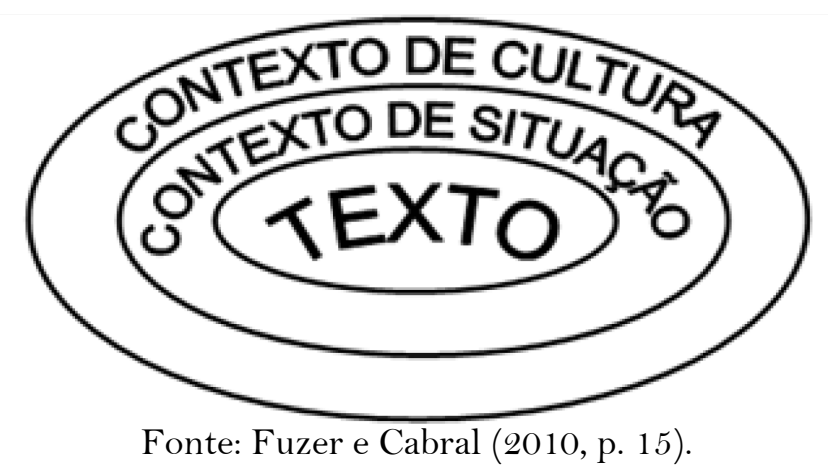

Proposto por Malinowski, em 1923, o contexto de cultura, de acordo com Halliday (1989), constitui os conhecimentos institucional e ideológico que atribuem valor ao tex to e condicionam sua interpretação.

O contexto de situação, em suas três variáveis - Campo, Relações e Modo -, converge os componentes fundamentais para que a língua exerça sua função essencial: significar e comunicar/compartilhar significados. Na concepção sistêmico-funcional de linguagem, o texto deve ser analisado em correlação com o contexto ao qual se insere, ou seja, no caso deste trabalho, com o contexto do qual as cartas bíblicas fazem parte. Para Halliday (1989), as variáveis são entendidas como:

- Campo: refere-se à natureza da prática social, ao assunto, o que está acontecendo.

- Relações: refere-se à relação entre os participantes seus papéis e status.

${ }^{1}$ The term "text" refers to any instance of language, in any medium, that makes sense to someone who knows the language. (2004, p. 3). 
- Modo: refere-se à natureza do meio de transmissão e mensagem.

Assim, as variáveis afetam as escolhas linguísticas, visto que cada uma está ligada diretamente a uma das três metafunções da linguagem apontadas por Halliday (1989): ideacional, interpessoal e textual, respectivamente, que constituem os propósitos principais da linguagem.

Segundo concebem Halliday e Matthiessen (2004), a metafunção ideacional constrói os significados de nossa experiência do mundo exterior ou interior representando-os por meio do sistema de transitividade. A interpessoal expressa e estabelece as interações e os papéis assumidos pelos usuários da linguagem, revelando atitudes desses usuários para com o interlocutor e para com o tema abordado por meio do sistema de MODO e modalidade. A metafunção textual está ligada ao fluxo de informação e organiza a textualização por meio do sistema de Tema e Rema.

Essas três metafunções, conforme Halliday e Matthiessen (2004), não se dão de forma isolada nos textos, mas sim simultaneamente. Pensando nisso, nas três subseções seguintes abordamos resumidamente os três significados funcionais da linguagem e os respectivos sistemas que os realizam, haja vista que são essenciais para desenvolver a análise das duas cartas bíblicas.

\subsection{Metafunção Ideacional}

A metafunção ideacional nos permite constituir e representar experiências de diferentes maneiras de acordo com o contexto do qual participamos (HALLIDAY; MATTHIESSEN, 2004). Tendo a oração como unidade de representação, essa metafunção, para Halliday e Matthiessen (2004), realiza-se ao nível léxicogramatical pelo sistema de transitividade.

O sistema de transitividade, de acordo com Ghio e Fernández (2008), pode ser definido tanto como um recurso gramatical formador do fluxo de experiência, quanto como um processo realizado gramaticalmente pela oração. Esse sistema léxico-gramatical constitui-se de três componentes: processo, participante e circunstância, na perspectiva da GSF, de acordo com Halliday e Matthiessen (2004), caracterizam-se como categorias semânticas que explicam como os fenômenos de nossas experiências do mundo são construídos na estrutura linguística.

Na concepção de Halliday e Matthiessen (2004), um processo ou uma atividade podem ser realizados por participantes em determinada circunstância. O processo é o elemento que indica a experiência se desdobrando através do tempo. Sua categoria gramatical típica é o grupo verbal, que pode ser agrupado em três grandes grupos: material, mental e relacional. Além desses centrais, há três grupos intermediários: verbal, comportamental e existencial.

Na GSF, cada tipo de processo envolve diferentes tipos de participantes. De acordo Halliday e Matthiessen (2004), os participantes de cada processo são as entidades envolvidas, como as pessoas ou coisas, seres animados ou inanimados. Realizam papéis como, por exemplo, de Ator, Beneficiário, Portador, Experienciador, Dizente. As circunstâncias se referem, por exemplo, a tempo, modo, causa, lugar. O Quadro 01 apresenta os tipos de processos, significados e participantes a eles associados.

Explanados os principais conceitos concernentes à metafunção ideacional, de modo específico no que tange aos significados ideacionais experienciais, passamos agora à segunda metafunção da linguagem, a interpessoal. 
Quadro 01 - Tipos de processos e participantes

\begin{tabular}{|c|c|c|c|}
\hline Processo & Significado & $\begin{array}{c}\text { Participantes } \\
\text { obrigatórios }\end{array}$ & EXEMPLOS \\
\hline Material & $\begin{array}{l}\text { Expressam o fazer ou } \\
\text { acontecer de uma entidade; } \\
\text { materializam linguisticamente } \\
\text { experiências } \\
\text { exterior. }\end{array}$ & $\begin{array}{l}\text { Ator; Meta; } \\
\text { Beneficiário; } \\
\text { Escopo; Atributo. }\end{array}$ & 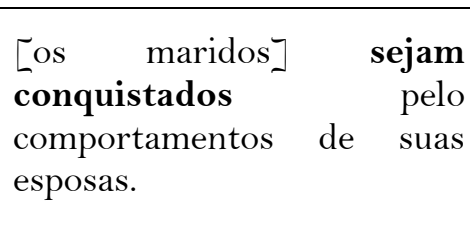 \\
\hline Mental & $\begin{array}{l}\text { Expressam experiências do } \\
\text { universo interior, ou seja, } \\
\text { realizam processos de pensar, } \\
\text { sentir, perceber e querer. }\end{array}$ & $\begin{array}{l}\text { Experienciador } \\
\text { Fenômeno }\end{array}$ & Sara obedeceu a Abraão. \\
\hline \multirow{2}{*}{ Relacional } & \multirow{2}{*}{$\begin{array}{l}\text { Servem para estabelecer } \\
\text { relações entre duas entidades, } \\
\text { para caracterizar (atributivo) } \\
\text { ou identificar (identificativo). }\end{array}$} & $\begin{array}{l}\text { Portador } \\
\text { Atributo }\end{array}$ & $\begin{array}{lll}{[\text { mulheres }]} & \text { sejam } \\
\text { submissas } & \text { aos } & \text { vossos } \\
\text { maridos. } & & \end{array}$ \\
\hline & & $\begin{array}{l}\text { Identificado } \\
\text { Identificador }\end{array}$ & $\begin{array}{l}\text { Mas [o vosso adorno }] \\
\text { consista na personalidade } \\
\text { que se esconde no vosso } \\
\text { coração. }\end{array}$ \\
\hline Verbal & $\begin{array}{l}\text { Expressam o dizer, realizam o } \\
\text { processo de comunicar, dizer, } \\
\text { explicar }\end{array}$ & $\begin{array}{l}\text { Dizente } \\
\text { Verbiagem } \\
\text { Receptor } \\
\text { Alvo }\end{array}$ & $\begin{array}{l}\text { Mas sejam submissas como } \\
\text { diz também a lei. }\end{array}$ \\
\hline Existencial & $\begin{array}{l}\text { Representam o que existe ou } \\
\text { acontece. }\end{array}$ & Existente & $\begin{array}{l}\mathrm{Na} \text { época antiga, havia } \\
\text { mulheres submissas. }{ }^{2}\end{array}$ \\
\hline Comportamental & $\begin{array}{l}\text { Representam formas de } \\
\text { comportamentos } \\
\text { e psisiológicosógicos } \\
\text { humanos. }\end{array}$ & $\begin{array}{l}\text { Comportante } \\
\text { Comportamento }\end{array}$ & $\begin{array}{l}\text { As mulheres choram na } \\
\text { condição de submissas. }\end{array}$ \\
\hline
\end{tabular}

Fonte: adaptado de Fuzer e Cabral (2010, p. 103), com base em Halliday e Matthiessen (2004).

\subsection{Metafunção interpessoal}

Ao informar, questionar, ordenar ou fazer uma oferta, explicam Halliday e Matthiessen (2004), expressamos avaliações e estabelecemos relações ou adotamos posicionamentos em uma determinada situação de interação. O estabelecimento e a manifestação dessas relações são funções intrínsecas da metafunção interpessoal que, segundo os autores, realiza-se por meio dos sistemas léxico-gramaticais de MODO e modalidade.

No sistema de MODO, a oração é analisada como uma troca entre o falante/escritor e o ouvinte/leitor em um evento comunicativo (HALLIDAY; MATTHIESSEN, 2004). Esse sistema, defendem Halliday e

\footnotetext{
${ }^{2}$ Não há exemplos de processos existenciais na constituição do corpus analisado; assim, a frase foi criada para exemplificação do processo.

${ }^{6}$ Não há exemplos de processos existenciais na constituição do corpus analisado; assim, a frase foi criada para exemplificação do processo.
} 
Mathhiessen (2004), fornece diferentes alternativas para a realização da interação, considerando o papel exercido pelo interlocutor e a natureza da negociação que está sendo realizada. Dessa maneira, o falante pode optar pelo uso do modo declarativo, interrogativo ou imperativo. As escolhas das funções de fala envolvem categorias de declaração, pergunta, oferta e comando. O Quadro 02 sintetiza as funções de fala descritas na GSF (HALLIDAY; MATTHIESSEN, 2004):

Quadro 02 - Funções de fala

\begin{tabular}{|c|c|c|}
\hline \multirow{2}{*}{ DAR } & BENS E SERVIÇOS & INFORMAÇÃO \\
& $\begin{array}{c}\text { OFERTA } \\
\text { Você quer saber se a mulher é submissa } \\
\text { ao homem?3 }\end{array}$ & $\begin{array}{c}\text { DECLARAÇÃO } \\
\text { As mulheres eram submissas aos seus } \\
\text { maridos. }\end{array}$ \\
\hline SOLICITAR & $\begin{array}{c}\text { COMANDO } \\
\text { Mulheres perguntem a seus maridos em } \\
\text { casa. }\end{array}$ & $\begin{array}{c}\text { Pulheres, vocês querem ser submissas aos } \\
\text { seus maridos? }\end{array}$ \\
\hline & PROPOSTA & PROPOSIÇÃO \\
\hline
\end{tabular}

Fonte: adaptadas a partir de Fuzer e Cabral (2010, p. 105), com base em Halliday e Matthiessen (2004).

Segundo Halliday e Matthiessen (2004), a linguagem, em eventos interativos, exerce papéis de "dar" e "solicitar". Quando se dá uma informação, faz-se uma declaração; quando se dá um bem e/ou serviço, faz-se uma oferta. Por outro lado, quando se solicita uma informação, faz-se uma pergunta e, quando são solicitados bens e serviços, dá-se uma ordem. Halliday e Matthiessen (2004) esclarecem que as trocas entre os interlocutores, quando constituem informações, são denominadas proposições e, quando constituem bens e serviços, são nomeadas propostas.

Significados interpessoais, acrescentam Halliday e Matthiessen (2004), também são realizados por marcadores de polaridade (sim, não, nenhum, nada), sinalizando sentenças afirmativas ou negativas. Ademais, podem ser usados recursos intermediários que situam a fala entre um polo negativo e outro positivo, que corresponde à modalidade. A modalidade é um recurso léxico-gramatical que expressa significados relacionados ao julgamento do falante em graus de positividade e negatividade.

A noção de modalidade está entre a distinção de proposições e propostas, denominadas de modalização e modulação, conforme Halliday e Matthiessen (2004). Segundo os autores, a modalização ocorre na troca de informações, sinalizando graus de probabilidade e usualidade. Podem ser expressos por recursos léxicogramaticais como verbos modais (poder, dever) e adjuntos modais (talvez, possivelmente, certamente, sem dúvida). A modulação, por sua vez, aparece em propostas, sinalizando graus de obrigação (permitido, aceitável, obrigatório) ou de inclinação (desejoso, determinado, disposto).

De acordo com Halliday e Matthiessen (2004), a essas categorias, acrescentam-se como recursos gramaticais de interpessoalidade os vocativos, as estruturas interrogativas, os marcadores atitudinais (infelizmente, felizmente, com prazer, pesarosamente, francamente) e Atributos avaliativos (interessante, prudente, horrível).

Explicitada e conceituada essencialmente a metafunção interpessoal, tratamos na sequência da terceira e última metafunção, a textual, que é responsável pela organização dos significados experienciais e interpessoais em um todo coerente.

\footnotetext{
${ }^{3}$ Os exemplos que constituem o quadro são adaptados do corpus.
} 


\subsection{Metafunção textual}

A metafunção textual concebe a oração como mensagem e é responsável por estruturar os significados ideacionais e interpessoais de maneira coerente, a fim de dar um status de texto (HALLIDAY; MATTHIESSEN, 2004).

De acordo com Halliday e Matthiessen (2004), a GSF fornece dois sistemas paralelos de análise que organizam a mensagem em um texto, quais sejam: estrutura da informação e estrutura temática. A estrutura da informação relaciona-se ao que é Dado é ao que Novo. O elemento Dado é de conhecimento mútuo entre os interlocutores, diz respeito ao que é "conhecido" no contexto, por conseguinte, é opcional. O elemento Novo, salientam os autores, é obrigatório e refere-se ao desconhecido, mas é recuperável pelo/no contexto.

A estrutura temática é constituída de duas partes: Tema e Rema. O Tema, de acordo com Halliday e Matthiessen (2004), caracteriza o ponto de partida da oração e, para identificá-lo, é necessário ter conhecimento sobre a metafunção ideacional, uma vez que o Tema "é o primeiro termo da oração que tem alguma função na estrutura experiencial" (HALLIDAY; MATTHIESSEN, 2004, p. 66) ${ }^{4}$. O Rema é o que segue após o Tema, ou seja, o restante da oração.

Em relação ao Tema, Halliday e Matthiessen (2004) apontam duas classificações básicas: marcado e não marcado. O Tema marcado corresponde àquele que foge ao que seja típico na língua; o Tema não-marcado, ao contrário, corresponde àquele considerado típico, "esperado". Em relação aos significados que expressa, sob o ponto de vista de Halliday e Matthiessen (2004), o Tema pode, ainda, ser classificado como ideacional (tópico), interpessoal e textual. O Tema ideacional pode ser identificado como o primeiro elemento da oração na estrutura da transitividade e pode ocorrer como:

- participante - ${ }^{5} \mathrm{O}$ vosso adorno não consista em coisas externas tais como, cabelos trançados, jóias de ouro, vestidos luxuosos. Na oração, o vosso adorno é o participante que está tematizado.

- processo - Era assim que se adornavam outrora, as santas mulheres [...]. Na oração exemplificada, o processo era é tematizado.

- circunstância - Da mesma forma, mulheres, sede submissas aos vossos maridos. No exemplo, a circunstância, da mesma forma é tematizado.

O Tema interpessoal ocorre quando há presença de vocativos, que identifica o locutor na troca, ou quando usa o Adjunto para exprimir comentário, opinião ou mesmo uma avaliação (HALLIDAY; MATTHIESSEN, 2004). Na oração [...] mulheres, sede submissas aos vossos maridos, por exemplo, o Tema é constituído por um vocativo, caracterizando-o como um Tema interpessoal.

Por último, o Tema textual, com base em Halliday e Matthiessen (2004), liga orações e geralmente realizase por meio das conjunções, as quais ligam uma sentença à outra. Essa ligação resulta em relações de dependência (hipotaxe) ou de independência (parataxe), por meio de pronomes relacionais. Também pode se realizar por meio de conetivos que estabelecem uma relação coesiva com o discurso anterior (além disso, desse modo), como ocorre, por exemplo, em Assim, Sara obedeceu a Abrãão, em que é tematizado o elemento coesivo assim, configurando um Tema textual.

Apresentados os pressupostos teóricos que orientam este trabalho, passamos, a seguir, às considerações metodológicas.

\section{METODOLOGIA}

Nesta seção, são apresentadas informações acerca da contextualização e da constituição do corpus de análise deste trabalho. Também são expostos os procedimentos metodológicos que nos guiam na realização das análises em busca de representações para a mulher.

\footnotetext{
${ }^{4}$ We shall say that the Theme of a clause is the first group or phrase that has some function in the experiencial structure of the clause
}

${ }^{5}$ Os exemplos de processo, participante e circunstância são retirados do corpus. 


\section{- Universo de análise}

O site http://www.bibliacatolica.com.br/ disponibiliza para consulta e download 25 Bíblias em 12 idiomas diferentes, oferecendo, inclusive, um ícone de comparação entre diferentes traduções. A Bíblia selecionada como fonte foi traduzida pela Conferência Nacional dos Bispos do Brasil (CNBB) e publicada no ano 2010. $A$ busca e a seleção dos textos ocorreram por meio do ícone "busca" pela palavra-chave "mulher" e semelhantes, como "esposa" no que corresponde ao Novo Testamento. Como resultado, foram encontradas 20 cartas que atendiam ao critério estabelecido. Para este artigo, porém, tendo em vista as restrições de tempo e espaço, foram selecionadas, de modo aleatório, duas cartas bíblicas para constituir o corpus de análise, conforme apresentado no Quadro 03.

Quadro 03 - Constituição do corpus

\begin{tabular}{|c|c|c|}
\hline Código & Título do texto bíblico & Localização na Bíblia \\
\hline T\#1 & $1^{\text {a }}$ Carta de Pedro & Capítulo $3-$ versículo 1 ao 8. \\
\hline T\#2 & $1^{\text {a }}$ Carta aos Coríntios & Capítulo $14-$ versículo 34 ao 40. \\
\hline
\end{tabular}

\section{- Passos para a análise}

Com base nos pressupostos teóricos da GSF, de Halliday e Matthiessen (2004), adotamos os seguintes passos para a análise:

- descrição do contexto de situação a partir das variáveis Campo, Relações e Modo. (HALLIDAY, 1989).

- categorização das funções léxico-gramaticais desempenhadas pelos itens lexicais em análise;

- análise das marcas de interpessoalidade (funções de fala e polaridade);

- verificação da estrutura textual por meio do mapeamento dos Temas;

- análise e interpretação dos resultados em busca de representações evidenciadas linguisticamente para a mulher a partir dos significados ideacionais (transitividade), significados interpessoais (funções de fala e polaridade) e textuais (posição temática).

Ao longo da análise do corpus selecionado, a seguir apresentada, os excertos sobre os quais versão as discussões são referidos pelos códigos $\mathrm{CP}$ ( $1^{\mathrm{a}}$ Carta de Pedro $)$ e CC $\left(1^{\mathrm{a}}\right.$ Carta aos Coríntios) e as orações são numeradas de acordo com a sequência em que são trazidas à análise.

\section{ANÁLISE E DISCUSSÃO DOS RESULTADOS}

Nesta seção, apresentamos as evidências linguísticas encontradas na CP e na CC. Buscamos interpretá-las e relacioná-las entre si a fim de atender ao objetivo deste artigo de evidenciar como a mulher é representada nesses textos sob o ponto de vista da GSF, a partir da aplicação de categorias de análise advindas das três metafunções da linguagem.

Inicialmente, na seção 2.1, analisamos os textos bíblicos em termos de sua Configuração Contextual, levando em consideração as três variáveis do contexto de situação proposto por Halliday (1989) - Campo, Relações e Modo. Logo após, na seção 2.2, analisamos os significados ideacionais experienciais, interpessoais e textuais, considerando que foram interpretados em conjunto.

\subsection{Configuração Contextual}

A Bíblia surgiu da oralidade, tendo sua primeira versão impressa por Guttemberg, segundo Labrador (2010), somente no século XV, tornando-se o livro mais vendido da história. Além disso, foi traduzida 
várias vezes, o que gerou grandes especulações sobre a sua veracidade. No que diz respeito à variavel Campo, os textos bíblicos são textos que abordam diferentes temas, no entanto, todos ligados aos ensinamentos de vida e direcionados aos homens e às mulheres em geral. Apresentam-se sob a forma de parábolas, evangelhos, cartas e epístolas.

Tanto a $1^{\text {a }}$ Carta de Pedro quanto a $1^{\text {a }}$ Carta aos Coríntios buscam abordar considerações diversas para a comunidade a que se dirigem, como podemos conferir no Quadro 4, que traz a descrição da Configuração Contextual (doravante CC) dos dois textos.

Quadro 04 - Configuração Contextual da Primeira Carta de Pedro e da Primeira Carta aos Coríntios

\begin{tabular}{|c|c|c|}
\hline $\begin{array}{l}\text { Variável de } \\
\text { Registro }\end{array}$ & CC $1^{\text {a }}$ Carta de Pedro & CC $1^{\text {a }}$ Carta aos Coríntios \\
\hline Campo & $\begin{array}{l}\text { transmissão de uma mensagem para } \\
\text { homens e mulheres. A mensagem faz } \\
\text { referência à fé, ao amor entre as pessoas, } \\
\text { às diferentes situações (vida em } \\
\text { comunidade, casamento, comportamentos } \\
\text { da mulher e do homem). "Deve-se ver } \\
\text { nesta carta uma expressão da } \\
\text { preocupação da igreja de Roma para com } \\
\text { os irmãos oprimidos num canto afastado } \\
\text { do império. É, portanto, um documento } \\
\text { intereclesial e intercultural muito } \\
\text { relevante para os nossos dias".(BÍBLIA, } \\
\text { 2010, p. 1494). }\end{array}$ & $\begin{array}{l}\text { transmissão de uma mensagem para homens } \\
\text { e mulheres, fazendo referência à fé, ao amor, } \\
\text { à vida em comunidade, ao bom } \\
\text { procedimento para com todos. Escrita por } \\
\text { Paulo durante a Segunda viagem } \\
\text { missionária, em 50/51 d.C. Uma carta } \\
\text { circunstancial, um diálogo a distância" } \\
\text { (BIBLIA, 2010: 1399). Ainda, "a finalidade é, } \\
\text { em primeiro lugar, pôr fim aos } \\
\text { partidarismos" (Ibidem) e "remediar as } \\
\text { práticas inadmissíveis na jovem comunidade } \\
\text { da cidade dissoluta" (Ibidem). }\end{array}$ \\
\hline Relações & $\begin{array}{l}\text { Apóstolo Pedro manifesta opiniões e } \\
\text { aconselhamentos para as comunidades } \\
\text { "do norte da Ásia Menor (Turquia), } \\
\text { habitado de "colonos" assentados pelo } \\
\text { império Romano, gregos e bárbaros } \\
\text { (outros povos). (BÍBLIA, 2010, p. 1494). } \\
\text { Eram consideradas pessoas excluídas da } \\
\text { sociedade, "sem-casa e sem pátria". Estão } \\
\text { envolvidos o homem, a mulher, o } \\
\text { Apóstolo. Entre o Apóstolo, homem e a } \\
\text { mulher há uma relação assimétrica. Entre } \\
\text { o homem e mulher há um grau de } \\
\text { familiaridade, a distância entre eles é } \\
\text { média. }\end{array}$ & $\begin{array}{l}\text { Apóstolo Paulo manifesta opiniões e } \\
\text { aconselhamentos, direcionada à comunidade } \\
\text { de Coríntios. Estão envolvidos o homem, a } \\
\text { mulher, o Apóstolo da comunidade de } \\
\text { Coríntios. Entre o Apóstolo, homem e a } \\
\text { mulher há uma relação assimétrica. Entre o } \\
\text { homem e mulher há um grau de } \\
\text { familiaridade, a distância entre eles é pouco } \\
\text { menos que máxima. }\end{array}$ \\
\hline Modo & $\begin{array}{l}\text { A linguagem tem papel constitutivo; o } \\
\text { modo é escrito e o meio é gráfico e } \\
\text { impresso. }\end{array}$ & $\begin{array}{l}\text { A linguagem tem papel constitutivo; o modo } \\
\text { é escrito e o meio é gráfico e impresso. }\end{array}$ \\
\hline
\end{tabular}

As CCs das cartas bíblicas mostram pontos convergentes e divergentes entre os autores do texto. Identificamos que tanto as Relações como o Modo são semelhantes nos textos. Obviamente que a época, a localidade e o direcionamento são distintos. A diferença mais acentuada consiste no Campo, haja vista que cada um dos textos abordam assuntos e objetivos diferentes. Salientamos, no entanto, que embora os textos sejam destinados para comunidades específicas (comunidade da Ásia menor, atual Turquia e Coríntios), a leitura é aberta, uma vez que durante o texto não é marcado claramente o seu direcionamento. Prova disso é o fato de que, até hoje, essas cartas bíblicas, assim como as demais, continuam sendo lidas e discutidas nas igrejas, católicas ou não. Da mesma forma, as pessoas continuam as lendo, refletindo sobre elas. Isso demonstra que, mesmo tendo sido produzidas em um contexto específico - e distante - e para um público específico, elas podem ser lidas, entendidas, aplaudidas, criticadas ou seguidas ainda hoje. Mesmo 
transcorrido tanto tempo, elas mantêm sua importância e popularidade, caso contrário a Bíblia não seria tão lida e comercializada.

Conhecido o contexto que envolve essas cartas e que nelas está representado, segundo o pressuposto hallidayano de que o texto influencia o contexto e o contexto influencia o texto, passamos à análise da linguagem com o propósito justamente de verificar, nesse contexto, que representação para a mulher é reproduzida.

Significados Ideacionais, Interpessoais e Textuais na construção de representaçoes para a mulher

Com base na descrição léxico-gramatical das duas cartas bíblicas $-1^{\mathrm{a}}$ Carta de Pedro e $1^{\mathrm{a}}$ Carta aos Coríntios - identificamos cinco representações principais para as mulheres, quais sejam: (i) submissas, (ii) responsáveis pela conduta de seus maridos, (iii) menosprezadas socialmente, (iv) humildes e (v) frágeis.

No excerto a seguir, na oração (1), a representação da submissão pode ser verificada, tendo em vista que a participante mulheres desempenha a função de Portador do Atributo submissas aos vossos maridos, o que já evidencia sua representação, que é reforçada pela função de fala comando a ela direcionada, o que é evidenciado pela tematização de mulheres como vocativo.

(1) Da mesma forma, mulheres, sede submissas aos vossos maridos (2) para que os que ainda não dão ouvidos à Palavra (3) sejam conquistados pelo comportamento de suas esposas, (4) mesmo sem discursos, pois hão de observar a vossa conduta casta no temor. [T\#1]

Na oração (3), a representação evidenciada para a mulher é outra: de responsável pela conduta do homem. Ao ser desempenhada pelo participante suas esposas, a função de Ator do processo material sejam conquistados evidencia que o exemplo de conduta deve ser da esposa, por meio de atitudes corretas a fim de influenciarem os maridos para que façam o mesmo. Dessa forma, acarreta um grau de responsabilidade sobre a mulher, como evidencia a polaridade positiva que acompanha o processo material sejam conquistados. Na oração (4), a construção léxico-gramatical ressalta mais uma vez que a responsabilidade recai na conduta da mulher, uma vez que a participante mulheres está associada à vossa conduta casta, que desempenha a função de Fenômeno do processo mental hão de observar polarizado positivamente.

Recorrendo à análise da CC, podemos inferir que essa representação, de um lado, ameniza a condição de ser "inferior" em uma sociedade em que a mulher não tinha vez, pois atribui-se a ela um papel muito importante; de outro lado, reforça essa sua condição, pois essa representação sugere a interpretação de que, se o homem não for um ser virtuoso, não tiver uma boa conduta, a culpa não é dele, mas sim da sua esposa.

Nas orações (5) e (6) que seguem, novamente a representação da mulher como um ser submisso às ordens de outrem é verificada.

\section{(5) Assim, Sara obedeceu a Abraão, (6) [Sara] chamando-o seu senhor. [T\#1]}

Na oração (5), a presença da intertextualidade faz referência ao casal Sara e Abraão, cuja história foi contada no Livro Gênesis, capítulo 20, da Bíblia. Sara, Experienciador do processo mental desiderativo obedeceu, é representada como mulher que vivenciou o sentimento de obediência, o qual, levando em consideração o contexto da época, devia ser mantido pelas mulheres em geral. Isso está evidenciado pela proposição que realiza a função de fala declaração com polaridade positiva. A tematização de Sara, que nesse caso representa as mulheres, corrobora a representação da mulher como submissa e obediente aos homens (nesse caso, representados por Abraão).

A oração (6) fortalece essa representação da mulher, uma vez que demonstra como Sara dirigia-se ao seu marido Abraão, evidenciado pelo processo verbal chamando e o Atributo seu Senhor. O uso do pronome de tratamento Senhor confirma a representação, haja vista que o pronome é utilizado na comunicação com pessoas com as quais há certo distanciamento e hierarquização social de poder. Isso pode ser comprovado, reportando-nos novamente à CC das cartas, na variável Relações, em que se verifica a existência de uma distância social média entre os participantes. Nesse sentido, a estrutura léxico-gramatical corrobora a CC, e vice-versa. 
Essa representação de submissão da mulher, agora não apenas ao homem, ao esposo, mas também às leis, é destaque também no excerto seguinte, na oração (10), ao assumirem - as mulheres - a função de Portador do Atributo submissas. Ainda nesse trecho, nas orações (8) e (9), uma nova representação que, de certa forma, reforça a submissão, é verificada: a de menosprezada socialmente.

(7) Como se faz em todas as igrejas dos Santos, (8)as mulheres guardem silêncio nas reuniões. (9) Não lhes é permitido tomar a palavra, (10) mas [mulheres] sejam submissas como diz também a lei. [T\#2]

Na oração (7), as mulheres desempenham a função de Ator do processo material guardar acompanhado do Escopo Processo silêncio. Assim, observadas a função de fala comando, realizada pelo modo oracional imperativo, e a polaridade positiva que indicam uma ordem direcionada às mulheres, evidenciada pelo Tema ideacional que explicita a quem é dirigida a ordenação: às mulheres. Esse comando é emitido a fim de que as mulheres mantenham silêncio em locais públicos, conforme sugerido pela circunstância nas reuniões.

Dessa forma, associada à representação de submissão, percebe-se, a representação de menosprezadas socialmente, à medida que a elas não é dado o direito à palavra, a manifestarem-se publicamente, em locais de relevância social, como é explicitado na oração (9). Nessa oração, o participante mulheres, (retomado pelo pronome lhes) é o Beneficiário-Cliente do processo material é permitido. No entanto, percebemos que não há benefício algum para as mulheres nesse processo, uma vez que o processo material está polarizado negativamente, indicando o que não é permitido que a mulher faça - tomar a palavra.

Essas representações de submissão ao marido, às leis e regras sociais e de menosprezo social construídas para a mulher é ratificada nas orações (11), (12) e (13) a seguir.

(11) Se [as mulheres] desejam informar-se sobre algum assunto, (12) perguntem a seus maridos em casa.

(13) Pois, não fica bem para a mulher falar numa reunião. [T\#2]

$\mathrm{Na}$ oração (11), as mulheres (em elipse) desempenham função de Experienciador do processo mental desejar. O processo polarizado positivamente, na oração 12 - perguntar - indica uma proposta por meio da função de fala comando, direcionado às mulheres. Nessa oração, o papel de Receptor é desempenhado por seus maridos, o que reforça a representação da mulher como submissa e ao esposo, uma vez que indica a quem a mulher deve direcionar suas perguntas. Ainda na oração (12), é tematizado o processo, indicando como as mulheres devem agir quando desejam informar-se sobre algum assunto.

Nos trechos que seguem, há exemplos que denotam uma quarta representação para as mulheres: humildes.

(14) O vosso adorno não consista em coisas externas, tais como, cabelos trançados, jóias de ouro, vestidos luxuosos, (15) mas na personalidade que se esconde no vosso coração, (16) marcada pela estabilidade de um espirito suave e sereno, coisa preciosa diante de Deus.[T\#1]

$\mathrm{Na}$ oração (14), o participante Portador vosso adorno associa-se aos enfeites utilizados pela mulher na composição do visual, coisas externas, como cabelos trançados, jóias de ouro, vestidos luxuosos, aqui léxicogramaticalmente como Atributos, por meio de uma forma verbal polarizada negativamente no MODO declarativo, denotando uma verdade dada, incontestável: não consista. Nesses termos, a representação sugerida para a mulher é de um ser humilde, que deve preocupar-se com a sua personalidade, que, por sua vez, deve ser marcada pela estabilidade de um espirito suave e sereno. Ao tematizar o vosso adorno, temos enfatizada a preocupação com a aparência das mulheres, que deve ser simples.

$\mathrm{Na}$ oração (15), o Atributo circunstancial na personalidade que se esconde no vosso coração reforça que o adorno a ser prezado pela mulher não deve ser material e aparente, mas sentimental e espiritual. Dito de outra forma, a representação sugerida para a mulher não é de um ser que precisa ser belo externamente, mas sim internamente, sendo puro e suave.

Nas orações seguintes, há a retomada das representações para a mulher como submissa ao marido e o como um ser humilde. 
(17) Era assim que se adornavam outrora, as santas mulheres, (18) que colocavam suas esperanças em Deus,

(19) [as santas mulheres] eram submissas aos seus maridos. [T\#1]

Na oração (17), a circunstância de tempo - outrora - ratifica a representação de que a mulher deve ser humilde. Juntamente com o elemento textual assim, que retoma o modo como as mulheres se adornavam, e com o Tema ideacional realizado pelo processo era, evidenciando o desdobramento da experiência através do tempo (HALLIDAY; MATTHIESSEN, 2004), a representação da mulher humilde é posta como algo que se perpetua ao longo do tempo e reforçada pelo argumento de que a humildade era praticada por santa mulheres. Dito de outro modo, a humildade é colocada como santificadora, em consequência, temos que a mulher deve desejar/buscar a representação de um ser abençoado, santificado.

No excerto abaixo, verificamos a manifestação da quinta representação que se destaca nos textos: a mulher como um ser frágil, mais delicado em relação aos homens. Ao representá-las como Portador de uma constituição mais delicada, podemos interpretar esse Atributo, aparentemente positivo, também como um reforço à representação da mulher como inferior ao homem, haja vista sua delicadeza, que pode ser associada à fragilidade. Em virtude dessa fragilidade, se comparada aos homens, sua submissão a eles e aos maridos é potencializada.

(20) De igual modo, vós, os maridos, convivei de modo sensato com vossas mulheres, (21) tratando-as com respeito por sua constituição mais delicada.[T\#1]

Dado o exposto, percebemos que as representações construídas linguisticamente para a mulher tendem predominantemente a desfavorecê-la, tanto - e principalmente - em relação ao homem, ao marido, quanto em relação à sociedade enquanto ambiente regrado, orientado por leis e costumes.

\section{CONSIDERAÇÕES FINAIS}

Por meio da análise linguística, realizada a partir de categorias das três metafunções da linguagem ideacional, interpessoal e textual -, especificamente das categorias léxico-gramaticais do sistema de transitividade, do sistema de MODO e polaridade e do sistema temático, pressupostos teóricos da GSF de Halliday e Matthiessen (2004), foi possível verificar que funções a mulher e os itens lexicais a ela correspondentes desempenham na oração e como ela é representada.

Com base na interpretação dos dados obtidos com as análises dessas categorias nas duas cartas bíblicas $-1^{\mathrm{a}}$ Carta de Pedro e $1^{a}$ Carta aos Coríntios -, podemos destacar cinco representações sobresselentes para a mulher: (i) submissa, (ii) responsável pela conduta de seu marido, (iii) menosprezada socialmente, (iv) humilde e (v) frágil.

Dentre as evidências linguísticas que nos levaram a essas cinco representações, estão a tematização de Temas ideacionais, como circunstâncias de modo comparação (da mesma forma), que aludem ao homem e, principalmente, à mulher, associando a eles comportamentos que devem ser seguidos. Esse teor de obrigatoriedade é evidenciado pelas funções de fala, predominantemente propostas, ou seja, imposições de condutas de modos de ser e agir direcionada principalmente à mulher, como é evidenciado por Temas interpessoais constituídos pelo item lexical "mulher" como vocativos.

Essa imposição é reforçada na estrutura da transitividade, em que a mulher, embora apareça linguisticamente em posições de Ator, Experienciador e Portador, na prática, esses papéis não se mantêm. Os processos que realizam encontram-se no modo imperativo, que, como já mencionado, evidenciam propostas. Ora polarizados positivamente, ora negativamente, esses processos representam como ela - a mulher - deve ou não agir de acordo com o que lhes é ditado como regra de conduta. Nesse sentido, evidencia-se que a representação que se destaca para a mulher e mantém-se recorrente ao longo dos textos é a da mulher submissa ao homem, ao marido e à sociedade. Em resumo, é representada como um ser submisso às ordens de outrem; um ser que não tem atitudes próprias, pois vive em um contexto que lhe obriga a agir conforme lhe é determinado. 
Dado o exposto, podemos constatar que a aplicação de categorias de análise fundadas na GSF hallidayana possibilitou-nos não apenas identificar representações para a mulher, objetivo principal das análises aqui apresentadas, mas também evidenciar as marcas linguísticas que verbalizam e manifestam tais representações. Com isso, acreditamos que este trabalho possa contribuir para a ampliação e comprovação da aplicabilidade e eficiência das categorias teórico-metodológicas inerentes à LSF. Além disso, as evidências léxico-gramaticais verificadas podem ser apontadas, com o desenvolvimento de análises futuras, como um possível padrão para a representação da submissão.

\section{REFERÊNCIAS}

ASSUMPÇÃO, M. As representações da mulher profissional brasileira e norte-americana construídas pela mídia impressa. São Paulo, 2008.131fl. Dissertação (Mestrado em Letras) - Pontifícia Universidade Católica de São Paulo, São Paulo, 2008.

BÍBLIA. Português. Carta aos Efésios. Bíblia Sagrada: Antigo e Novo Testamento. Tradução: Conselho Nacional dos Bispos do Brasil. São Paulo: Ed. Canção nova, 2010.

BARBARA, L.; MACEDO, C. M. M. Linguística Sistêmico-Funcional para a Análise de Discurso: um panorama introdutório. Cadernos de linguagem e sociedade, v. 10, p. 89-107, 2009.

CABRAL, S.R.S. Estrutura textual e transitividade: a carta do leitor como construção da experiência. Santa Maria: UFSM, 2002. Dissertação (Mestrado em Letras), Universidade Federal de Santa Maria, Santa Maria, 2002.

A mídia e o presidente: um julgamento com base na teoria da valoração. Santa Maria: UFSM, 2007. Tese (Doutorado em Letras), Universidade Federal de Santa Maria, Santa Maria, 2007.

CALDEIRA, J. R. A redação de vestibular como gênero: configuração textual e processo social. Rio de Janeiro: PUC-RIO, 2006. Tese (Doutorado em Letras), Pontifícia Universidade Católica, Rio de Janeiro, 2006.

DALLA CORTE, S. Modos de organização do discurso e representação de um governo latino-americano no gênero reportagem. Santa Maria: UFSM, 2009. Dissertação (Mestrado em Letras), Universidade Federal de Santa Maria, Santa Maria, 2009.

FARENCENA, G.S. Estudo da fábula: contexto, linguagem e representação. Santa Maria: UFSM, 2011. Dissertação (Mestrado em Letras), Universidade Federal de Santa Maria, Santa Maria, 2011.

FUZER, C. Linguagem e representação nos autos de um processo penal: como operadores do direito representam atores sociais em um sistema de gêneros. Santa Maria: UFSM, 2008. Tese (Doutorado em Letras), Universidade Federal de Santa Maria, Santa Maria, 2008.

FUZER, C; CABRAL, S. R. S. Introdução à gramática sistêmico-funcional em língua portuguesa. Santa Maria: Universidade Federal de Santa Maria, Centro de Artes e Letras, Departamento de Letras Vernáculas, Núcleo de Estudos em Língua Portuguesa, 2010.

GHIO, E; FERNANDEZ, M. D: Linguística Sistémico-Funcional: aplicaciones a La leingua española.Santa Fé: Universidad Nacional Del Litoral,WaldhuterEditores, 2008.

HALLIDAY, M. A. K; MATTHIESSEN, C. An introduction to systemic functional grammar. London, UK: Arnold Publishing, 2004.

HALLIDAY, M. Part I. In: HALLIDAY, M.A.K e HASAN. Language, context, and text: aspects of language in a social-semiotic perspective. Oxford: Oxford University Press, 1989.

HASAN, R. Part II. In:HALLIDAY, M.A.K e HASAN, R. Language, context, and text: aspects of language in a social-semiotic perspective. Oxford: Oxford University Press, 1989.

HOERLLE, E. A permanência da leitura da Bíblia como prática social diante das transformações de produção e distribuição pelo mercado brasileiro.In: CONGRESSO BRASILEIRO DE CIÊNCIAS DA COMUNICAÇÃO DA UFRGS, 32,2009, Porto Alegre. Anais eletrônicos... Rio Grande do Sul: UFRGS, 2009. Disponível em: http://www.intercom.org.br/papers/nacionais/2009/resumos/R4-2064-1.pdf. Acesso em: 08 jun.2013.

LAVRADOR, J.L.P. Ao sabor da Bíblia. Coimbra, 2010. 227fl. Dissertação (Mestrado em Letras) Universidade de Coimbra, Coimbra, 2010. 
MARTIN, J. R.; WHITE, P. The language of evaluation: appraisal in English. New York: Palgrave, 2005.

MORAIS, C.B.F. As mulheres na política brasileira: um estudo sob a perspectiva sistêmico-funcional. São Paulo, 2008. 1 19fl. Dissertação (Mestrado em Letras) - Pontifícia Universidade Católica de São Paulo, São Paulo, 2008.

OLIVEIRA,C.A.E. A expressão da identidade feminina na música funk: uma análise do gênero letras de canções da fase erótica do movimento funk brasileiro. Tubarão, 2007. 114fl. Dissertação (Mestrado em Letras) Universidade do Sul de Santa Catarina, Tubarão, 2007.

RODRIGUES, L.C.C. "Se quiser, é assim:” Uma análise léxico-gramatical da representação feminina em letras de forró eletrônico. João Pessoa, 2010. 174fl. Dissertação (Mestrado em Letras) - Universidade Federal da Paraíba, João Pessoa, 2010.

SILVA, T.S. Irenes: representações sobre homossexuais idosos no contexto midiático sob a perspectiva Sistêmico-Funcional. Santa Maria: UFSM, 2012. Dissertação (Mestrado em Letras), Universidade Federal de Santa Maria, Santa Maria, 2012.

SAYÃO, J. O jornalismo literário e as falas de seus entrevistados: um estudo de Linguística Sistêmico-Funcional. São Paulo: PU-SP, 2011. Dissertação (Mestrado em Letras), Pontifícia Universidade Católica de São Paulo, São Paulo, 2011.

VAN LEEUWEN, T. A representação dos actores sociais. In: PEDRO, E. R. (Org.). Análise Crítica do Discurso. Lisboa: Caminho, 1997. p. 16

\section{ANEXO - CARTAS BÍBLICAS ANALISADAS}

\section{$1^{\mathrm{a}}$ Carta de Pedro}

As esposas

$3{ }^{1}$ Da mesma forma, mulheres, sede submissas aos vossos maridos para que os que ainda não dão ouvidos à Palavra, sejam conquistados pelo comportamento de suas esposas, mesmo sem discursos, ${ }^{2}$ pois hão de observar a vossa conduta casta no temor.

${ }^{3} \mathrm{O}$ vosso adorno não consista em coisas externas, tais como cabelos trançados, jóias de ouro, vestidos luxuosos, ${ }^{4}$ mas na personalidade que se esconde no vosso coração, marcada pela estabilidade de um espírito suave e sereno, coisa preciosa diante de Deus.

${ }^{5}$ Era assim que se adornavam, outrora, as santas mulheres, que colocavam suas esperanças em Deus. Eram submissas aos seus maridos.

${ }^{6}$ Assim, Sara obedeceu a Abraão, chamando-o seu senhor. E vós sois filhas de Sara, se praticais o bem, sem que medo algum vós perturbe.

Os maridos

${ }^{7}$ De igual modo, vós, os maridos, convivei de modo sensato com vossas mulheres, tratando-as com respeito por sua constituição mais delicada e por elas serem como vós herdeiras da graça da vida. Isto, para que vossas preces não encontrem obstáculo.

\section{$1^{\text {a }}$ Carta aos Coríntios}

Como se faz em todas as igrejas dos Santos, 34 as mulheres guardem silêncio nas reuniões. Não lhes é permitido tomar a palavra, mas sejam submissas, como diz também a Lei.

35 Se desejam informar-se sobre algum assunto, perguntem a seus maridos, em casa. Pois não fica bem para a mulher falar numa reunião. 